\title{
Dezombies and the Coming Design Apocalypse: Confronting the Urgent Need to Increase Racial Diversity and Environmental Awareness in University-Level American Communication Design Programs
}

ERIC BENSON, ${ }^{1}$ JOHN JENNINGS; ${ }^{2}$ ADDITIONAL CONTRIBUTIONS AND EDITING BY MICHAEL R. GIBSON ${ }^{3}$

1. Associate Professor of Graphic Design, University of Illinois at Urbana-Champaign, IL, USA

2. Professor of Media and Cultural Studies, the University of California at Riverside, Riverside, CA, USA

3. Professor of Communication Design, Graduate Programs Coordinator, Design Research and Interaction Design, The University of North Texas, Denton, TX, USA

SUGGested CITATION: Benson, E., Jennings, J., \& Gibson, M.R. “Dezombies and the Coming Design Apocalypse: Confronting the Urgent Need to Increase Racial Diversity and Environmental Awareness in University-Level American Communication Design Programs.” Dialectic, 1.2 (2017): pgs. 129-154. DOI: http://dx.doi.org/10.3998/dialectic.14932326.0001.207

\section{Abstract}

When movie director George Romero introduced the modern conception of the zombie in his film "Night of the Living Dead" in 1968, he created an enduring metaphor for depicting the societal impact of rampant conspicuous consumption. His allegory for the consumer is that of a mindless, empty shell of a being who is only connected to its fellow humans by its incessant need to have its ravenous hunger satiated by the consumption of living brain tissue. The persona of the zombie metaphorically represents the demise of free thought and critical analysis in society. Romero's film depicts one of the most significant and historically persistent horrors of humanity - our seemingly insatiable need to consume — set against the isolation and banality of our existence in a world now largely driven by corporate agendas.

This piece will argue the position that the contemporary American design practitioner and educator directly and indirectly create exemplifications of the persona of Romero's zombies by the millions across much of the world, and particularly in the U.S. We do this when the bulk of what we teach design students to think about and do is limited to creating and disseminating the pretty packages that hold the metaphorical "brains - the processed food products, the consumer goods, the promise of life-altering services and experiences - that consumers mindlessly devour many times over as they live their lives. 



\title{
Dezombies and the Coming Design Apocalypse:
}

\author{
Confronting the Urgent Need to Increase Racial Diversity \\ and Environmental Awareness in University-Level American \\ Communication Design Programs
}

ERIC BENSON \& JOHN JENNINGS;

ADDITIONAL CONTRIBUTIONS AND EDITING BY MICHAEL R. GIBSON

a In the context of this article, "communication design" refers to a university-level program of learning that may also be referred to as a program with any of the

following degree titles: graphic design, visual communications, visual communication design, interaction design, advertising design, or multimedia design.

NASAD (National Association of Schools of Art and Design). “Higher Education Arts Data Services (HEADS) Project, Chart 61: 'Art/ Design Students by Degree Level and Ethnic Characteristics, '" HEADS Data

Surveys, 31 January 2011. Online. Available to NASAD members with data access privileges at: https://secure3.vaultconsulting.com/ HEADS/NASAD/SpecReqForm.aspx. (Accessed June 26, 2017).
Introducing the Key Contextual Factors that Fuel "Dezombieism"

As described here, DeZombies are the products of an educational system in and around American university-level communication design that no longer effectively prepares its students to practice design ethically or responsibly given the current socio-economic, political and environmental state of our planet. Too much of contemporary American university-level communication design curricula is assumptively but erroneously structured to teach students to become versant at designing to satisfy the expectations of a single stakeholder, as opposed to preparing them for the modern reality of having to work to meet the expectations of multiple, diversely informed stakeholders. We refer to this type of myopically framed and informed communication design education as DeZombieism.

The current pedagogical models and cost of tuition in so many of the roughly 2,300 two- and four-year university-level communication design a programs around the U.S. tend to limit opportunities for cultural experiences and intellectual growth on behalf of many of their students - especially those who are minorities of African American, Hispanic or Latino origin. According to the National Association of Schools of Art and Design (NASAD), of the approximately 103,000 students who enrolled in four-year, art or design Bachelor of Fine Arts (BFA) programs in the U.S. in 2010, only 3,600 were Black and only 4,300 were Hispanic or Latino. ${ }^{1}$ This means that only $3.5 \%$ of communication 
design "majors" in the U.S. were Black in 2010, and only $4.2 \%$ were Hispanic or Latino (accurate figures for Native American enrollment were unavailable as of this writing in July of 2017). With so few students and faculty of Black, Native American, Latino or Hispanic origin enrolled or teaching in university-level, American communication design programs, we argue that the spectrum of cultural experiences, learning, knowledge construction, and understanding on offer within them is too limited when compared to how this spectrum operates across our increasingly diverse society. In these types of settings, DeZombieism thrives.

The result of this is university-level communication design curricula in the U.S. - and, from what we can discern from here, in much of western Europe, Australasia, the Middle East and South America - perpetuates the teaching of conceptual, 'Euro + Caucasian-aesthetic-trumps-all' approaches and norms. These are also overwhelmingly culturally biased to reinforce a narrowly confined range of behaviors and aspirations that are societally acceptable and appropriate. They also help perpetuate socio-economic barriers to secondary education in design, and, more broadly, the social sciences and the humanities in general, for many under-represented groups. Additionally, this type of curricula often doggedly reinforces prescribed, aesthetically-pleasing-but-narrowly-framed social and cultural outcomes to design processes: the kinds that DeZombies typically produce. In turn, their perpetuation promotes the sociocultural and socio-economic mindset that the primary means to improving the "common good" lies only in designing work that promotes exorbitant consumerism, regardless of how doing this might affect the future best interests of our natural environment, and the way all who must share it live now and in the future.

To counter this, which means taking a stand against DeZombieism, we argue for the development of new systems of university-level, communication design curricula that allow for input from diverse social and cultural influences and that more readily afford access to students who hail from a broader array of America's socio-economic classes. We advocate for mandatory discussions about the ethics of working with or on behalf of (or against the interests of) particular clients, and the social, economic, technological and political impact that final products, systems or communities yielded by a given design process have on the resiliency of our natural environment. The curricula of contemporary university-level, communication design education should also encourage open dialogues among students, their faculty and design

\section{2}


${ }^{\mathrm{b}}$ According to data compiled by the AIGA Design Educators' Community (DEC) in three surveys conducted between August 2013 and August 2016. These same surveys indicated that there are approximately 1,700 two-year and "online certificate granting” programs operating in the U.S. This data is still being analyzed, and the research that is guiding its collection and organization is ongoing as of this writing in July of 2017. Generating finite, quantitative data in and around this area is difficult given the fact that new programs - roughly two to four dozen - are brought into being each year at a wide variety of American in stitutions of higher learning, while roughly the same number cease operations. professionals about designers who create and disseminate work that operates outside the global corporate oligarchy, and about how the professional practice of design can effectively support an inclusive manifestation of design processes as positive social practices, or practices that have the potential to change public policy, or both.

\section{The Need to Combat the "One Instructor, One Student, One Outcome" Model Of University-Level, American \\ Communication Design Curricula}

Current university-level, American communication design curricula is cemented in a mentor (most likely a Caucasian instructor) and mentee (student) model within which projects are assigned, working parameters and outcomes are largely predefined, and students work (mostly) independently in some form of a studio or atelier environment. This curricular model is relatively similar among many university-level institutions in the U.S. wherein a BFA or equivalent four-year undergraduate degree in communication design, graphic design, or, more recently, interaction design is offered (there are roughly between 725 and 800 of these ${ }^{b}$ ).We contend that, at least in the U.S., the maintenance of this model is counterproductive to the continued, positive evolution of the profession, and to the larger society as a whole that both affects and is affected by design decision-making.

At risk of stating the obvious, we contend that American, universitylevel communication design educators need to remind their students that the world outside of their classroom often functions in a very different manner than many of these classrooms imply that it does. Unlike the scenario most commonly operated in American communication design programs, design professionals often do not have a single person (in the form of an Instructor or a Professor) to answer to, nor do they have control over the exact size and scope of a given project from beginning to end. Instead, there are many layers, facets and conditions - variable and fixed, such as work environment, budget, and a given client's level of risk aversion — that, over its lifetime, affect a project that is undertaken for hire. It is important to note that we are not arguing for a classroom to operate like a commercial communication design consultancy or workplace, but instead that it operate to better reflect team-based learning with input from multiple stakeholders. (This is a distinctly 'anti-DeZombie' approach.)

So many of the project parameters American university-level communication design students are challenged to resolve limit the scope of their

\section{3}


criticality to empirical variables like medium, text, and image. These limited (and therefore limiting) parameters - often presented in the form of a tightly circumscribed "design brief" - usually challenge the student to create some type of designed ephemera in a pre-determined format (i.e., that of a specific type of periodical, website, mobile app, or brand identity campaign consisting of definitive artifacts). This presents quite a different, and limited, challenge compared to that of calling for the student to think about how and why a particular outcome to a design process - which may not necessarily yield a physical artifact - might affect the socio-culturally rooted thinking of a given audience or user group, or the future functioning of a given natural environment. The most pressing issues that face society in the 21st century and beyond are large and complex systemic issues like climate change, poverty, racism, and the perpetuation of natural and economic stability and sustainability.

This small sampling of humanity's concerns are given short shrift as discussion topics in far too many university-level, American communication design classrooms. This situation will likely worsen as large portion of society's most potentially creative emerging minds are cooped up in American communication design programs where what they are being taught is being framed by a handful of dated, tightly framed and formulaic project parameters. These types of assignments call for students to produce a limited array of pre-determined, artifact-based outcomes, like "expressive typography" posters, two-page pamphlets, page-spreads for hipster magazines and logos for the latest iterations of tech startups. This over-focus on ephemeral artifact creation as the end-all of the design process prevents students from 1) identifying and then exploring how they - as designers - might most effectively respond to many of the most significant social, technological, environmental, economic and public policy challenges we face as a society today, and 2) prevents them from having to plan and design complex systems of visual communication that require organizing different types of data. Teaching students to design within such a narrowly defined scope of outcomes reinforces the idea to them that communication designers work on and affect only a small subset of what can be now be printed and digitally facilitated. As we as design educators (should now) know and understand, the communication design profession is much more diverse and robust than this, and continues to grow in its exploration and construction of new knowledge.

Curricular and pedagogic progress in U.S.-based communication design classrooms has certainly been made in recent years, but the current

\section{4}


Frascara, J. “The Dematerialization of Design: A New Profile for Visual

Communication Design," ico-D, 8 November, 2006. Online. Available at: http://www.ico-d.org/connect/ features/post/76.php (Accessed 3 July 2017).

3

Krisch, I.S., Jungeblut, A. Jenkins, L., and Kolstad, A. "Adult Literacy in America: A First Look at the Findings of the National Adult Literacy Survey," U.S. Department of Education, 3 April, 2002. https:// nces.ed.gov/pubs93/93275.pdf. (Accessed June 25, 2017). approaches many American communication design educators take to their facilitation of instruction has remained largely staid. This has resulted in lots of book cover, wine label, magazine re-design and button-and-menu-driven user interface projects that only fit a narrow conception of what design is and can do and be, and that isn't all that different from student project work that was popular 20 or even 40 years ago. In this way, student portfolios become filled with print and digital work that is aesthetically beautiful but that is imbued with content that is only momentarily provocative and that addresses (mostly) corporate (i.e., for-profit), as opposed to social, environmental or public policy, concerns. Longtime communication design educator Jorge Frascara feels that design that is chiefly focused on addressing corporate concerns - a given for-profit entity's efforts to sustain or increase its market share-is inconsequential. "There is design to make life possible, design to make life easier and design to make life better. Irrelevant design is a liability for the profession and the environment." ${ }^{2}$ DeZombieism is rooted in this type of irrelevancy.

A typographic poster featuring beautifully kerned letterforms announcing the arrival of a new flavor of high fructose corn syrup-infused soda does not improve our quality of life (and in fact may detract from it if it somehow influences us to drink more of this unhealthy beverage), but it can improve the earnings of the corporation who commissioned it. It is considered by many to be a successful design artifact if it achieves the latter goal rather than the former. (This is an example of the type of design process outcome that Frascara has deemed irrelevant.) A better use of the communication design student's time might be to focus on finding a means to address the needs of the 40 million Americans who cannot read the delicately kerned typography created by communication designers, ${ }^{3}$ or the roughly $50 \%$ of Americans whose obesity can be traced, at least in part, to consuming foods and beverages of little or questionable nutritional value. (With that stated, we do not believe that designing beautiful typography and designing for the social good have to be mutually exclusive. They should both be essential to how we all design, and are all taught to design. A gorgeous design outcome that helps create or promote positive environmental or social welfare will have a greater, more enduring impact.)

By challenging so many of its students to focus on "solving design problems" within the narrow confines of (mostly) empirical parameters outlined predominantly by corporate interests, much of American communication design education is preparing students to identify and solve the wrong types of our society's problems. We are in danger of educating a generation of future

\section{5}


communication designers that have been predominantly prepared to address design challenges that have been narrowly and shallowly defined to meet the needs and aspirations of far too few. These "few" tend to belong to a social demographic that wields its cultural capital in ways that severely limit belonging. It often means you have to have emerged from a fairly upper-middle-class-tohigher environment, have lighter skin, and have been able raised so that you emerge from your teenage years knowing why espresso comes in a tiny cup, what barre techniques best alleviate lower-back pain, and how to discuss intersectionality without being accused of engaging in any type of micro-aggression. Aspiring designers who have exclusively accrued this type of cultural capital may require immersion in broadly informed, deeply probative learning experiences to avoid becoming DeZombies.

\section{Identifying Key Barriers to Diversifying the Social and Cultural Make- up of American, University-Level Communication Design Programs}

Beyond positively changing what and how we teach, helping the next generation of communication designers deal with the high cost of college is necessary to ensuring that a broad enough cross-section of them can proactively contribute to and participate in a future within which they might actually like to live. Ensuring that more than $10 \%$ of communication design students are white, which means ensuring that more Black, Native American, Latino and

Mitchell, T. "Chart: See 20 Years of Tuition Growth at National Universities," U.S. News \& World Report, 29 July 2015. Online. Available at: https://www.usnews. com/education/best-colleges/paying-for-college/articles/2015/07/29/ chart-see-20-years-of-tuitiongrowth-at-national-universities. (Accessed June 26, 2017).

5

Carnevale, A.P. \& Strohl, ]. "Separate \& Unequal: How Higher Education Reinforces the Intergenerational Reproduction of White Racial Privilege." Georgetown University Public Policy Institute, 9 July 2013. Online. Available at: https://cew.georgetown.edu/wp-content/uploads/2014/11/SeparateUnequal.FR_.pdf. (Accessed June 26, 2017). Pgs. 6-7. Hispanic students can afford to join their ranks as Bachelor's degree seekers, is a good place to start. A contemporary American University education has become quite expensive since state-based defunding efforts for public universities began in earnest nationwide in 2003 and 2004. Between 1995 and 2015, the cost of paying in-state tuition and fees at national universities increased by $300 \%$, from $\sim 2,500$ per year to $\sim \$ 10,000$ per year. ${ }^{4}$ Without mortgaging their future by taking on heavy student loans, these tuition costs are well beyond the economic reach of many Americans, particular those who are Black, Native American, Latino or Hispanic. This cost barrier creates conditions in many American communication design programs that results in their being predominantly populated by Caucasian and Asian students. These students are much more likely to have been raised in "more expensive housing in the suburbs with the best schools and peer support for educational attainment." ${ }^{5}$ They are also much more likely to have grown up in household where at least one parent has earned a college degree, compared to Black, Native American, Latino and Hispanic students, who are $42 \%$ less likely to have grown up in this type of a home 
Reardon, S. F., Baker, R. 8 Klasik, D. "Race, income, and enrollment patterns in highly selective colleges 1982-2004," Center for Education Policy Analysis, Stanford University, 3 August, 2012. Online. Available at: http:// cepa.stanford.edu/content/race-income-and-enrollment-patterns-highly-selective-colleges-1982-2004. (Accessed June 25, 2017).

\section{8}

Dwyer, L. “Why Aren't Black Students Picking Majors That Lead to High-Paying Jobs?" Takepart, 9 February 2016. Online. Available at: http://www.takepart.com/article/2016/02/09/black-studentsdont-pick-majors-high-paying-jobs/. (Accessed July 11, 2017).

\section{9}

Anderson, J.C. "Black Designers Still Fight for a Seat at the Table-Are They Finding Success?" Huffington Post, 11 October 2012. Online. Available at: http://www. huffingtonpost.com/2012/02/29/blackdesigners-artists_n_1280883.html . (Accessed June 26, 2017). environment. (Growing up in a household where at least one parent has earned a college degree increase the odds of their children earning a college degree by about $60 \%) .{ }^{6}$

White students are also much likely to enroll in America's most selective American colleges, academies and universities - communication design is offered as a four-year, BFA degree in over 80 of these, about half of which are private institutions - than Black, Native American, Latino and Hispanic students. These more selective (i.e., more competitive to gain admission into) institutions also tend to cause students enrolled in their communication design programs to need an increasing amount of financial aid from U.S.-government-subsidized Pell Grants and other forms of loans, fellowships and scholarships. White students are more likely to successfully navigate the complicated processes necessary to secure higher levels of this type of support than their Black, Native American, Latino and Hispanic counterparts, and "white students are five times as likely to enroll in a highly selective college as Black students and almost three times as likely as Hispanic students." ${ }^{7}$

If they can gain entry into a highly selective American institution of higher learning and the often even more selective communication design curriculum that operates within it, Black, Native American, Latino and Hispanic students tend to be the first in their immediate and often extended family to enroll in any type of university curriculum. Students of Color also often encounter pressure to major in professions that may guarantee them larger professional salaries upon completion of selective entry degree programs, such as medicine, law, engineering, and business. Although a career path in communication design can sometimes yield a relatively high salary-especially if the student accrues education and training in user experience or interaction design - it tends NOT to be a professional discipline that is highly touted in Native American, Latino and Hispanic households in the U.S. Careers in the visual arts and design are touted even less in Black households, which results in less than $3 \%$ of Black undergraduate students choosing to major in these disciplines. ${ }^{8}$

One of the primary reasons for this is the under-representation of Americans of Color in our history of the Design disciplines, combined with the lack of many designers of Color being widely known outside their professions. ${ }^{9}$ It is relatively easier for parents in Black, Native American, Latino and Hispanic households to discuss the lives and careers of more well-known doctors, lawyers, politicians, and business leaders of Color with their children 
10

Miller, M. "Survey: Design Is

73\% White," Fast Co. Design, 31 January 2017. Online. Available at:

https://www.fastcodesign.com/ 3067659/survey-design-is-73-white.

(Accessed June 26, 2017). than it is for them to discuss the lives and careers of designers of Color. These factors also contribute to the fairly low likelihood that American communication design students will encounter a communication design educator of Color as they progress through their degree programs. This can further narrow the scope of the aesthetic, empathic, and cultural influences that White students and students of Color are exposed to as they engage in their coursework. This limitation then extends and is compounded as entry-level designers enter the workforce, where, according to the AIGA's 2016 Design Census Survey, 73\% of the professionals and educators working and teaching communication design in the U.S. today are White. ${ }^{10}$

We argue that the combination of factors described here help perpetuate negative stereotypes involving race-or, specifically, a lack of diversity thereof - in and around communication design as it is currently taught and practiced in the U.S. We also argue that these factors have diminished awareness of and sensitivity about the diverse array of cultural influences necessary and relevant to the perpetuation of a diverse American, and, beyond that, global society. The upshot of this is that it has rendered communication design education, as it currently administrated, planned, and taught in the U.S., to be inadequate regarding its need to effectively prepare students not only to enter, but to sustain careers within the profession. Simply put, the financial and cultural barriers to entry into the university-level programs that prepare one for entry into the profession are, at present, too steep for too many American people of Color to overcome. In turn, this means that that too many university-level, American communication design programs are far too homogenously populated and informed to effectively counter "DeZombieism," or the kind of monoculture within which individual DeZombies, or groups of them, are born and developed.

\section{How Dezombies are Created and Nurtured, and What Can Be Done to Defeat (Or, Better Yet, Prevent) Them}

The approaches to American communication design education described in the previous sections of this piece creates and nurtures DeZombies: design students who are guided by myopically informed, socio-economically, often white-washed corporatism, who are taught to repeatedly create the same types of outcomes derived from shallowly interrogated design processes in a vicious cycle designed to perpetuate current popular cultural trends. DeZombies leave their degree programs with a paucity of real visual literacy (they have learned 
to appropriate and to mimic, but not how to invent and innovate, much less to engage in either of these activities collaboratively), and more often than not are unaware of the how the ephemera they create affect social, technological, environmental, economic and public policy perceptions and actions. The education and training they receive too often positions them to have to beg for jobs as service providers working on behalf of corporations and corporate interests that often leave a path of environmental and cultural destruction as a result of their manufacturing and dissemination practices. This article champions the idea that what could well evolve into a DeZombie Apocalypse-across the U.S. and eventually the world - can only be stopped with the planning and implementation of a dramatic shift in communication design education that employs the in-depth exploration and application of sustainable systems thinking. This type of thinking challenges communication design students and educators to attempt to achieve three related goals:

1. to examine and question a given challenge as part of an entire system of connected concerns, and

2. to do this by engaging in a deeply probative, broadly informed discussion of the complex variety of social, technological, economic and public policy issues facing contemporary society, and

3. to examine how design affects and is affected by these.

As described here, DeZombies are the products of an educational system in and around American university-level communication design that no longer effectively prepares its students to practice design ethically or responsibly given the current socio-economic, political and environmental state of our planet. As has been stated previously in this piece, too much of contemporary American university-level communication design curricula is assumptively but erroneously structured to teach students to become versant at designing to satisfy the expectations of a single stakeholder, as opposed to preparing them for the modern reality of having to work to meet the expectations of multiple, diversely informed groups.

Additionally, too many of the learning experiences that comprise contemporary, American university-level communication design curricula are based on what design theorist and philosopher Tony Fry describes as "the proposition that the designers and the design professions exist to provide services. De facto it means that frequently the most crucial design decisions have 
11

Fry, T. Design Futuring: Sustainability, Ethics and New Practice. London, UK: Berg, 2008, p.172. been made before the designer comes on the scene-decisions like the nature of what is to be created, its market placement, technology and materials." ${ }^{11}$ Much of American university-level communication design pedagogy dictates a given outcome for the student to realize in response to a specific "design problem" - a booklet, a website, a mobile app — without allowing for any discussion about whether that vehicle of dissemination is the best means to facilitate communication with or to a particular audience and, moreover, whether that response must be assessed solely on the basis of whether or not it advanced some aspect of consumerism. These approaches to design education help to create DeZombies that exist in a status quo network of solutions to assigned design problems. DeZombies live in a fungible world; that is, a society where everything has a price and market in which it can be sold or traded for a commodity that is judged to be of equal worth.

DeZombies are taught to think that the "answer" to a given communication design challenge exists only in the realm of what can printed or rendered on screen, and, that within those two possible arenas, only a limited number of specified artifacts (i.e. brochures, websites or apps of particular types) can be produced. Additionally, DeZombies tend to be quick to appropriate visual styles and subject matter that emerge as parts of new, mostly aesthetically rooted trends in communication design regardless of the ramifications these types of appropriations have on interpretation or meaning making among their audiences. This often means that DeZombies are slow to understand the social and historical relevance of, or the contextual frameworks that surround, that which they appropriate to create what, for them, in their small, homogenously inhabited worlds, is "new and original" work.

DeZombies also tend to cultivate little knowledge about the political, environmental and social impacts of their printed and digital creations. The scope of what they are taught, or sensitized, to consider regarding the broad implications of their work is narrow because the educational experiences they have been immersed in have not challenged them to measure the affect or effect of their work beyond asking whether or not "the client" has been satisfied. This kind of thinking, and the behaviors its informs, also encourage DeZombies to consume resources to design and disseminate visual communications that exist primarily to sell products and services, rather than new ideas, or ways of thinking or making or behaving. The materials they make are ephemeral in nature, lasting only as long as the immediacy that contextualizes their limited messaging remains relevant, and destined, in the end, for the landfill or the 
virtual trash can. $30.8 \%$ of American landfills are comprised of a mutilated pile of torn, used-once-and-discarded packaging created by communication design professionals. ${ }^{12}$ Author and design educator DK Holland elaborates: “...(s)eemingly, design students and professors pick projects on a whim, develop it to some degree, present it and then move on, tossing it into ye ole landfill or, at best, filing it away. We need to get away from [this] dilettante mentality. (Which, like masturbation, is a lot of fun but what are you left with?)." 13

Far too much of university-level, American communication design curricula is currently constructed and operated as a rigid, immutable system designed to train - rather than educate - roughly 45,000 student “creatives" per year to design material that ensures increasing corporate profits and market share trump meeting the needs and satisfying the aspirations of actual people. In this scenario, facilitating consumption handily wins over facilitating citizenship as future designers learn to engage in design as a means to build a better brand rather than an intellectually more broad-minded, more inclusive, and therefore stronger, community. In this manner, most American communication design curricula does not educate experts to create and disseminate that which constitutes our visual culture (as one would imagine), but instead educates professionals who possess only a surface level of understanding about the real power of images and image systems to alter perceptions, to really change thinking.

“Municipal Solid Waste Generation, Recycling, and Disposal in the United States Detailed Tables and Figures for 2008," U.S. Environmental Protection Agency, 5 January, 2009. Online. Available at: http://www.epa.gov/epawaste/nonhaz/ municipal/pubs/msw2008data.pdf . (Accessed June 29, 2017).

13

Holland, DK. "Blow Up the Design School! Part 1," Communication Arts, 28 August, 2015. Online. Availabe at: http://www. commarts. com/column/blow-design-schoolpart-1. (Accessed June 25, 2017).

\section{4}

Newsom, J.S (Director).

“Miss Representation." San

Francisco, CA, USA: Girl's Club Entertainment, 2011. DVD.
A blatant example of this exists in the communication design academic and professional sectors' ongoing inability to effectively address, much less curtail, its complicity in perpetuating hyper-sexualized and demeaning portrayals of women across such a large cross-section of all-too-consumable visual media.

This ongoing failure of communication design educators and professionals is articulated in Jennifer Siebel Newsom's 2011 film “Miss Representation." ${ }^{14}$ It depicts a societal landscape in the U.S. within which women are still consistently and ubiquitously portrayed as one-dimensional objects that exist to be desired and consumed, and to be emulated for being desirable and consumable. Despite socially and politically motivated efforts to foster the visual communication of more broadly inclusive, less-one-dimensional portrayals and depictions of women across the hyper-mediated American visual landscape, these have been largely eclipsed by well-financed, well-strategized efforts to continue to "use" hyper-sexualized women to sell goods and services. The dominance of these types of portrayals of the female form in so much of what 


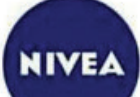

\section{NIVEA}

Mar 31 at 7:00pm • (2)

\section{Keep it clean, keep bright. Don't let anything ruin it, \#Invisible}

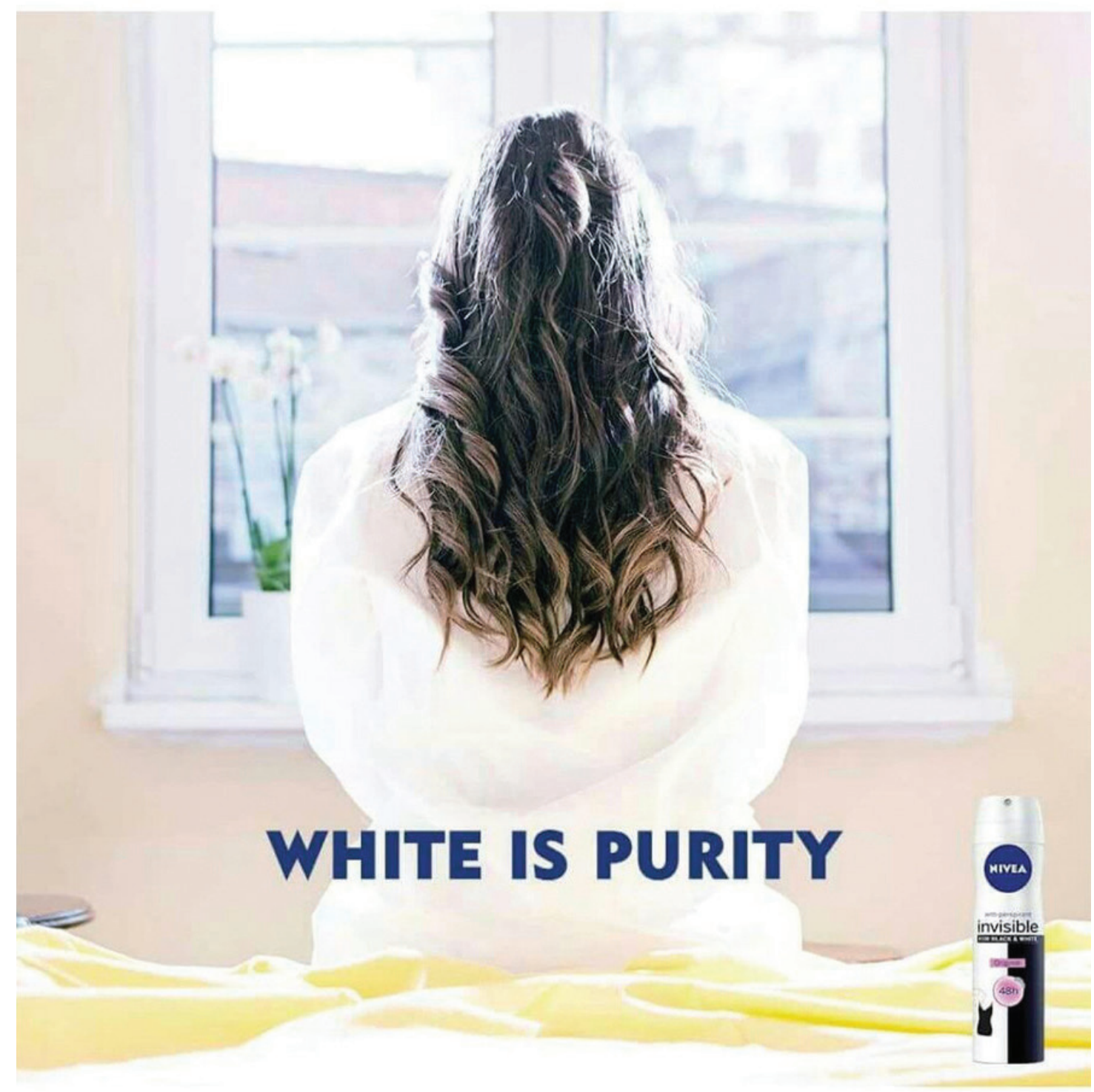

FIGURE 1: Nivea briefly ran its "White is Purity" ad campaign to promote its "Invisible for Black and White" deodorant product line in the spring of 2017. The campaign was targeted toward the company's followers in the Middle East, but was quickly pulled after it instigated a high volume of negative commentary on social media by many who felt it promoted racist rhetoric. 
Americans visually digest every day has been directly correlated to psychologically negative, female body issues and eating disorders among large numbers of American women: $65 \%$ of women and girls living in the U.S. have experienced disordered eating behaviors. This is a scenario within which university-level, American communication design education should be challenging emerging designers to develop, create and disseminate visual communications that defy, or seek to defy, these types of stereotypically negative portrayals of women. Achieving this goal will require that emerging American communication designers are educated to inform their design decision-making in a high degree of visual literacy, which in turn requires critical thinking, which is an activity that is antithetical to being a DeZombie.

The results of so many professional communication designers being visually illiterate, of allowing their social and cultural myopia to affect their design decision-making — of being DeZombies — are unfortunately not limited strictly to their inability to create depictions of women that are demeaning. This can and has also resulted in design work that promotes racist views. In March of 2017, the cosmetics company Nivea approved and paid to publish an advertisement in print and online that displayed a seated, dark-haired, female model facing away from the viewer on an unmade bed with a view out of what appears to be an urban apartment window on a sunny morning (Figure 1). The headline for this piece, which was marketed across the Middle East, was "White Is Purity." The subheadline for this piece was "Keep it clean, keep bright. Don't let anything ruin it, \#Invisible.” In 2006, the New York-based Art Director's Club (ADC) announced their "Pimp My Brand: 85th Annual Call for Entries" campaign in a poster that depicted a less-than-cheerful, Black Ronald McDonald "showing off his bling" in the form of a golden, ADC award cube while simultaneously converting a historic Black Power symbol (the afro) into a symbol of mockery as it supplanted Ronald McDonald's bright red coiffure (Figure 2).

These ads are but two among the many produced for public consumption by professional, university educated, communication designers in recent years that involve perpetuating a negatively stereotyped aesthetic in a visually provocative manner. The ads were cited by a wide variety of professional media critics, media producers (such as The New York Times and The Huffington Post) as being particularly disparaging to one or more ethnic groups. Much of the criticism of them involved posing questions about how they could have ever advanced through an internal vetting process far enough to be approved, much

\section{3}


less actuated, for publication. We hereby pose a slightly different question: how were former students of university-level communication design programs so poorly educated with regard to their social and cultural awareness as to think that these ideas should not have been killed in the earliest stages of their development? When cultural studies are non-existent, or given short shrift in university-level communication design curricula, it can be hard to keep DeZombies who create work of this sort from being created and nurtured.

Communication Designers' work predominantly appears on paper and, via digitization, on some form of a screen. For this to happen, an integrated, well-organized network of resource providers, vendors, manufacturers, transport operators, and, ultimately, audiences and users must be operationalized. The operationalization of networks like this generates significant amounts of types of pollution, including vast quantities of waste paper. Paper is the fourth largest contributor to greenhouse gas emissions in the United States, ${ }^{15}$ and manufacturing it causes it to be one of the largest consumers of industrial water among all OECD countries. ${ }^{16}$ Server farms that host the online creations of communication designers can use up to 70 billion Killowatt Hours of energy nationally per year, ${ }^{17}$ adding to the already growing, planet-warming, greenhouse gas mixture in our atmosphere. Many university-level, American communication design students who earn BA and BFA degrees are unaware of these facts, and enter the professional world as DeZombies without much useful understanding about how to use their design knowledge to decrease catastrophic climate change.

University-level, American communication design educators are too slowly recognizing the importance of critically interrogating the methods designers rely on to manufacture and disseminate the array of print and digital communications in ways that could minimize the negative economic, environmental and political impacts these methods are having on the planet and society. The American communication design profession has long been complicit in motivating the droves of rabid consumers that regularly pile into big, carbon emitting vehicles on their way to purchase consumable goods sold in big box stores across the U.S. Communication design manifest as advertising encourages large cross-sections of Americans to continuously gorge themselves on beautifully packaged, often unnecessary-to-use-or-own products through socially and culturally irresponsible messaging that exploits the most vulnerable aspects of our psyches: our needs to be acceptable to others, to be admired, or

\section{4}




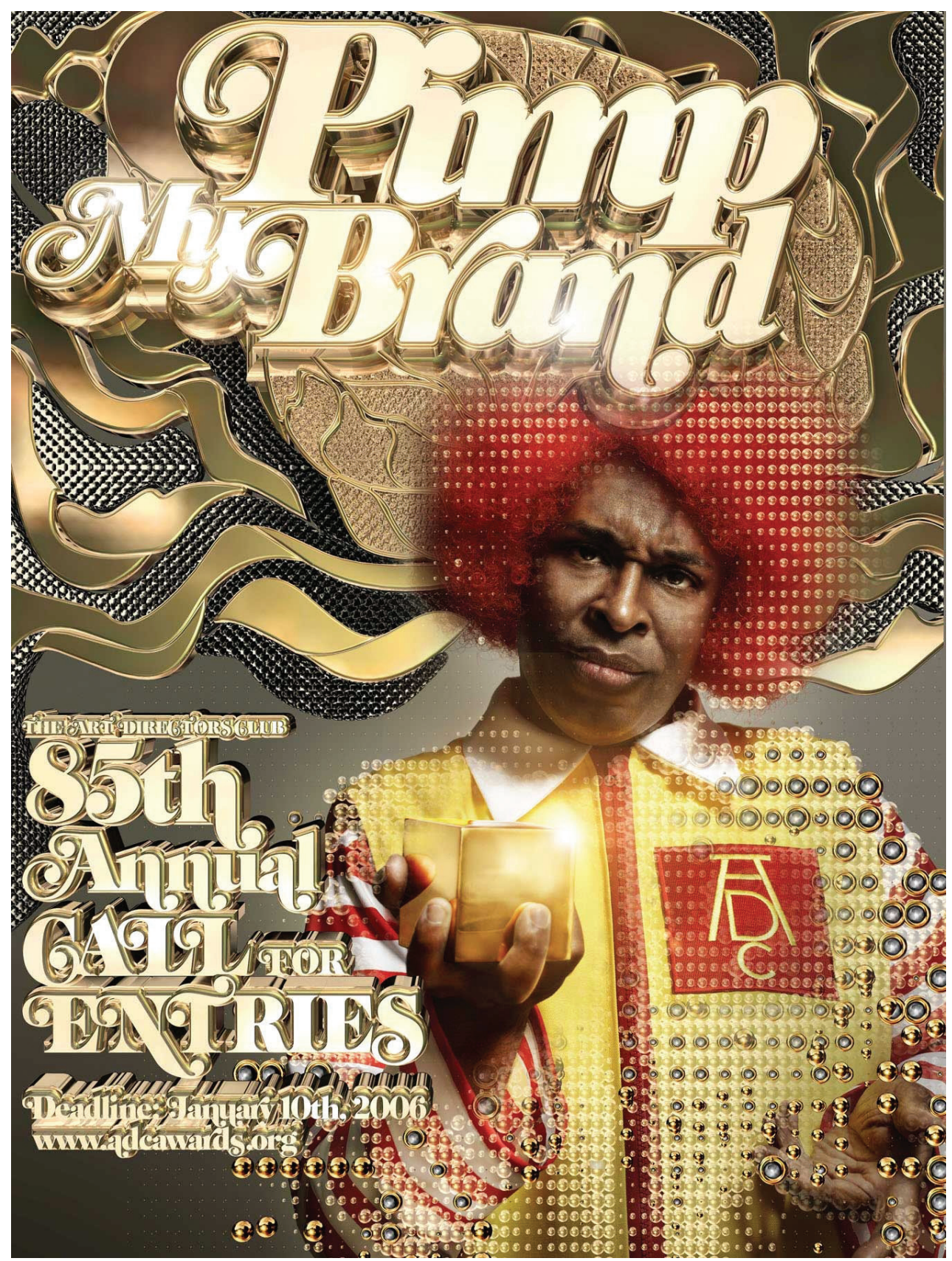

FIGURE 2: This promotional poster from the 2006 Art Director's Club "Pimp My Brand" campaign was negatively criticized in many professional design and advertising circles soon after it was disseminated in late 2005. Rick Poynor of Eye Magazine opined that "The Art Directors Club 85th annual call for entries may be the most off-the-mark piece of advertising ever produced by an organisation promoting the cause of communication." (Poynor, R. "Bad language: With Talk of 'Pimping Brands', the ADC's new campaign make design look dumber than ever." Eye Magazine, 5 January 2006. Online. Available at: http://www.eyemagazine.com/opinion/article/bad-languageweb-only (Accessed September 9, 2017). 
18

Fry, T. Design Futuring: Sustainability, Ethics and New Practice. London, UK: Berg, 2008, p.155.

19

Speth, J. G. America the Possible: Manifesto for a New Economy. New Haven, СT, USA: Yale University Press, 2012, pg. 4. 20

Papanek, V. The Green Imperative: Ecology and Ethics in Design and Architecture. New York, NY, USA: Thames \& Hudson, 1995, pg. 1.

21

Holland, DK. "Blow Up the Design School! Part 1," Communication Arts, 28 August, 2010. Online. Available at: http://www.commarts.com/ column/blow-design-school-part-1. (Accessed June 25, 2017). to be perceived as better than. If you can be made to feel less-than-happy with what you have, what you look like, or what type of vacation package you can afford, there is likely a DeZombie, or a team of them, who has designed or will design a visual communication that will suggest ways for you to purchase and consume your way to being at least somewhat happy again. In this way, the creative industry facilitates a peculiar kind of citizenship, one that requires the consumption - now, today - of the cool-looking stuff and services that our planet can continue to provide for a limited time only.

Author and design educator Tony Fry refers to engaging in this type of activity as "defuturing." He writes, “(b)luntly, what unsustainability and associated defuturing actions actually tell us is that the amount of time that humanity has to save itself from itself is very limited." "18 James Gustave Speth, a Professor of Law at the University of Vermont, agrees: “...our system gives priority to economic growth to the neglect and often the detriment of social and environmental needs." 19 The shift toward a more socially and environmentally responsible approach to planning and operating American, university-level communication design curricula is indeed occurring in a smattering of the nation's 2,300 programs, albeit this is not occurring fast enough, or in enough places. This pedagogical transformation no longer makes the question of teaching to address what design educator, activist and theorist Victor Papanek referred to in 1995 as "the green imperative" ${ }^{20}$ a source of debate, but it instead forces the prioritization of key questions about how to best facilitate the teaching of more socially, economically and environmentally responsible design practices. The war against DeZombieism in American, university-level communication design programs is and will be most effectively waged by design educators.

\section{Conclusion: Some Suggestions for Avoiding A Crushing Blow to the Head}

"Now is the time that everyone should be a designer and help disentangle the mess. Some of the biggest gnarls: human population explosion; environmental and wildife degradation; food and water shortage; extreme discrepancy between the 'haves and have-nots.' These humongous problems have only come into sharp focus in the last century as our access to information has opened up through technology.”21 


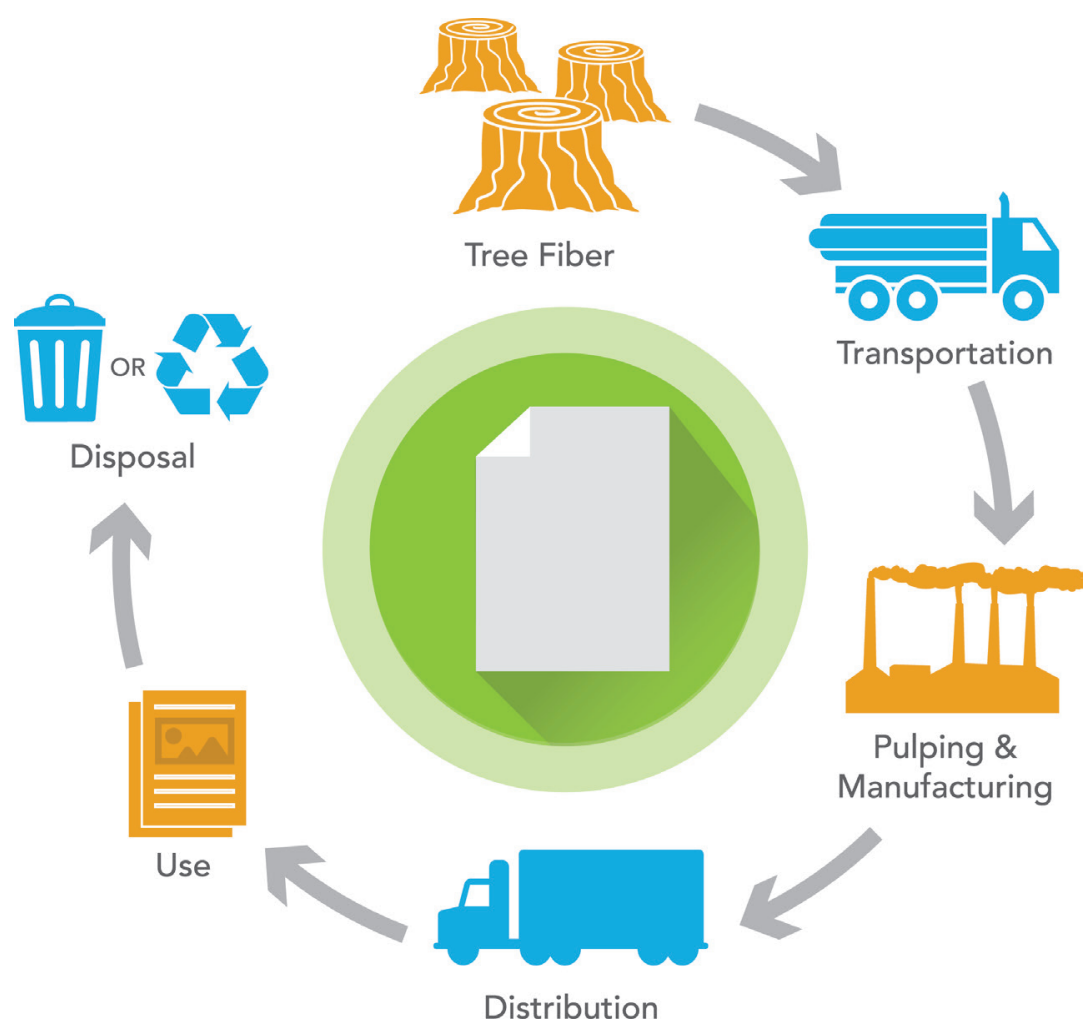

FIGURE 3: A graphically simplified depiction of the paper supply-to-disposal chain as it is currently operated in many of the industrialized nations in the world, such as the U.S., China, the U.K., Germany, France, Russia and India.

The social and cultural wasteland that could soon become (or perhaps already is, in many places) the communication design profession in the U.S. can be avoided. For this to occur, design education must address contemporary social, technological, economic, environmental and political issues more directly and consistently in the classroom through readings, discussions, and projects that instigate and effectively sustain positive social action. These types of learning experiences should not follow the mentor-mentee model, but instead challenge emerging designers to gather and analyze ongoing input from multiple stakeholders and contributors guided by systems-oriented approaches and methods. Structuring and facilitating curricula and project-based learning in this way creates more relevant work that lives outside of the classroom and positively impacts surrounding communities. Fry argues that the design profession must, “...forget design as a territory and practice that can be laid claim to (the drive of professionalization), stop talking to yourselves (the internal dialogue of design events), give up on repackaging design within design (collaborative design) 
22

Fry, T. Design Futuring: Sustainability, Ethics and New Practice. London, UK: Berg, 2008, p.3.

23

Muir, J. My First Summer in the Sierra. Boston, MA, USA: Houghton Mifflin, 1911, pg. 110. 24

Gibson, M.R. \& Owens, K.M. "Making Meaning Happen Between 'Us' and 'Them:' Strategies for Bridging Gaps in Understanding Between Researchers Who Possess Design Knowledge and Those Working in Disciplines Outside Design." In The Routledge Companion to Design Research, edited by P. A.

Rodgers \& J. Yee, pgs. 386-399. London, UK: Routledge, 2015. and start talking to other people, other disciplines; broaden your gaze (beyond the design process, design objects and design's current economic positioning), engage the complexity of design as a world-shaping force and help explain it as such.” 22

American, university-level communication design educators must employ sustainable systems thinking in their work, as the world is complex and connected, and growing more so. Environmental advocate John Muir first explained the wisdom inherent in this approach more than a century ago: “...(w) hen we try to pick out anything by itself, we find that it is bound fast by a thousand invisible cords that cannot be broken, to everything in the universe.” ${ }^{23}$ There are dozens, sometimes hundreds, of interwoven considerations that need be taken into account by students as a potential communication design challenge - like creating a poster — begins to be addressed. For starters, it is good idea to challenge students to examine the fundamental need for a given designed artifact to exist: "Is a poster the best means to visually communicate a particular message to a given target audience? (if not, what IS, and why?)" Students also need to be sensitized to pose other questions rooted in determining how much energy, water, tree fibers, ink, and time will be necessary to produce the piece. For this type of approach to work most effectively, classroom assignments must remove tightly circumscribed descriptions of the desired outcome from whatever set of "assignment parameters" or "brief" is given to the students at the outset of the project, and instead ask them to consider what the best response to a given set of communication needs might be.

Discovering or inventing a superlative design opportunity based on how this type of sustainable systems-thinking approach is operationalized requires a thorough examination of how a given designed artifact or system of them fits into the organization of resource procurement, manufacture, transport, use, and disposal, more-or-less in this order (Figure 3). Sustainable systems thinking approaches require that a given design challenge is informed by a consideration of the variable factors, users/audiences, non-variable conditions and socio-cultural issues that contextualize, or "frame," that particular challenge. ${ }^{24}$ It also requires careful consideration of the affects that our material and vendor choices have on one another, the planet, and, consequently on us. It still matters that communication designers understand our audiences and the economic viability of what we make, but also, "how the work we do is demanding of our natural resources, where and how we get materials to produce our projects, who and what is affected by our decisions, and what will 
happen to the project after it's handed off." ${ }^{25}$ Analyzing projects from system vantage points may also indicate to the designer that their initial response to whatever design challenge was posed may not have been one that was bestsuited for the situation. Visualizations like this can help emerging designers, along with a wide variety of project stakeholders and collaborators, better understand how decisions to design or utilize (or not) particular artifacts, and the resources and manufacturing energies they require, affect a wide variety of real-world processes.

University-level, American communication design educators must also ask themselves and the ever-diversifying array of contemporary design practitioners, "Who does the profession serve?" So much of the contemporary classroom dialogue in our discipline across the country is currently focused on locating and sustaining careers that serve a limited group of corporate oligarchs while avoiding discussions of how to effectively broaden the social, technological, economic and political horizons of the discipline. Are jobs for communication designers in social entrepreneurial sectors possible, and, if so, what might these (should these) look like? How can the communication design discipline achieve an effective transition from the broad perception by those outside it of us operating as mere service providers to us being proactive strategists capable of advancing, or collaborating to advance, particular social and cultural agendas?

American, university-level communication design educators must devote their primary focus toward working across disciplinary boundaries in both the private and the academic sectors to bring the knowledge and understandings only designers have to bear on the co-creation of a resilient, or "sustainable," natural environment. "Without sustainability neither we nor freedom have a future." ${ }^{26}$ A new ethos is necessary for change. Educators must educate each other and evolve to create problem seekers that are ready to tackle prevalent social and environmental problems. Design educators must also promote citizenship over corporatism through discussions of ethics, sustainability, and

25

Benson, E., \& Perullo, Y. “Design to Renourish: Sustainable Case Studies in Practice." Boston, MA, USA: CRC Press, 2016, pg. 5.

26

Fry, T. Design Futuring: Sustainability, Ethics and New Practice. London, UK: Berg, 2008, p.9. responsibility. They must also recommend to students that enrolling in classes in the social, environmental, and political sciences will bring much needed knowledge and inspiration to their studio-based projects.

Communication Design educators must also confront the challenges of rising tuition costs and increasing the opportunities of people of Color sitting in and leading the classroom. The former is definitely a challenging dilemma that is largely caused by ideological politicians and rising university 
27

AIGA. "Diversity \& Inclusion Initiative," AIGA, 2 February 2017. Online. Available at: http://www.aiga. org/diversity-and-inclusion-initiative/. (Accessed June 28, 2017). administration salaries. However, Communication Design Educators should not sit idly by and instead participate in the democratic process through voting candidates into office that support K-12 and higher education funding increases, and by using our visual communication skills to create more awareness among the general public about this issue. Increasing the racial diversity of student populations in university-level, American communication design classrooms is another extremely difficult challenge, but one that must be addressed, and addressed Now, lest our professional discipline be allowed to be perceived by non-designers as even more inconsequential and relevant to their success than it now is. Communication design educators need to join campus and nationwide initiatives and committees that help to create a welcoming and safe campus environment of mentorship and encourage increases in campus-wide investments to recruit and retain ethnic minority students and tenure-track faculty.

The AIGA (The Professional Association for Design in the U.S., also known as the American Institute for Graphic Arts, and who funds the publication of this journal), to their credit, has undertaken a recent "Diversity and Inclusion Initiative" that has been partially funded by the National Endowment for the Arts (NEA) to "support a more diverse audience of design students, practitioners, managers, thinkers, enthusiasts, clients, consumers, and policy makers.” ${ }^{27}$ The initiative has effectively solicited and includes input from practitioners and educators, and is thus a positive step. It will hopefully also lead to more students of Color being introduced to communication design as a viable career and life path during their high school, or 'pre-Collegiate' learning experiences. This will require that these students are taught by high school instructors who themselves have been introduced to design as a means to help their students learn to be more empathic, deeply reflective problem identifiers and solvers, which is - again — quite different than teaching design as a means to merely 'make stuff look cool.' The people who will most likely need to step forward and teach these American high school instructors to teach their students of Color of and about design are American, university-level design educators and practitioners.

American communication design educators and practitioners must face the challenges to our future by evolving and expanding our current pedagogy to be less insular and one-dimensional, less focused on teaching DeZombies to "make cool things." We must teach our students to get beyond the typical, narrowly framed, artifact-based outcomes that so many of us (and them) 
28

Fry, T. Design Futuring: Sustainability, Ethics and New Practice. London, UK: Berg, 2008, p.25. continue to equate with what communication design is and is supposed to accomplish. If we can do this successfully, or even moderately better than we are as of this writing, our discipline can finally evolve to the point epistemologically and ontologically where academics and professionals from beyond design might wish to collaborate with us more readily. Fry believes that “...design is one of the main operative agents of the social, cultural, and economic functioning and dysfunctioning of humanity's made world." ${ }^{28}$ Those of us who teach and practice design are, in other words, both the problem and the solution, and the best line of defense against.

\section{References}

AIGA. "Diversity \& Inclusion Initiative," AIGA, 2 February 2017. Online. Available at: http://www.aiga.org/diversity-and-inclusion-initiative/ (Accessed June 28, 2017).

Anderson, J.C. "Black Designers Still Fight for a Seat at the Table-Are They Finding Success?" Huffington Post, 11 October 2012. Online. Available at: http://www.huffingtonpost.com/2012/02/29/black-designers-artists_n_1280883.html (Accessed June 26, 2017).

Benson, E., \& Perullo, Y. Design to Renourish: Sustainable Case Studies in Practice. Boston, MA, USA: CRC Press, 2016.

Carnevale, A.P. \& Strohl, J. "Separate \& Unequal: How Higher Education Reinforces the Intergenerational Reproduction of White Racial Privilege." Georgetown University Public Policy Institute, 9 July 2013. Online. Available at: https://cew.georgetown.edu/wp-content/uploads/2014/11/SeparateUnequal.FR_pdf. (Accessed June 26, 2017).

Dwyer, L. “Why Aren’t Black Students Picking Majors That Lead to HighPaying Jobs?” Takepart, 9 February 2016. Online. Available at: http://www.takepart.com/article/2016/02/o9/black-studentsdont-pick-majors-high-paying-jobs/. (Accessed July 11, 2017).

Frascara, J. “The Dematerialization of Design: A New Profile for Visual Communication Design," ico-D, 8 November, 2006. Online. Available at: http://www.ico-d.org/connect/features/post/76.php (Accessed July 3, 2017).

Fry, T. Design Futuring: Sustainability, Ethics and New Practice. London, UK: 
Berg, 2008.

Gibson, M.R. \& Owens, K.M. “Making Meaning Happen Between 'Us’ and 'Them:' Strategies for Bridging Gaps in Understanding Between Researchers Who Possess Design Knowledge and Those Working in Disciplines Outside Design." In The Routledge Companion to Design Research, edited by P. A. Rodgers \& J. Yee, pgs. 386-399. London, UK: Routledge, 2015.

Helman, C. "Berkeley Lab: It Takes 70 Billion Kilowatt Hours A Year To Run The Internet." Forbes: Energy, 28 June, 2009. Online. Available at: https:/www.forbes.com/sites/christopherhelman/2016/06/28/howmuch-electricity-does-it-take-to-run-the-internet/\#4663b2ea1fff (Accessed July 2, 2010)

Holland, DK. "Blow Up the Design School! Part 1." Communication Arts, 28 August, 2010. Online. Available at: http://www.commarts.com/ column/blow-design-school-part-1. (Accessed June 25, 2017).

Krisch, I.S., Jungeblut, A., Jenkins, L., and Kolstad, A. “Adult Literacy in America: A First Look at the Findings of the National Adult Literacy Survey.” U.S. Department of Education, 3 April, 2002. https://nces.ed.gov/ pubs93/93275.pdf. (Accessed June 25, 2017).

Miller, M. “Survey: Design Is 73\% White.” Fast Co. Design, 31 January 2017. Online. Available at: https://www.fastcodesign.com/3067659/surveydesign-is-73-white (Accessed June 26, 2017).

Muir, J. "My First Summer in the Sierra." Boston, MA, USA: Houghton Mifflin, 1911.

"Municipal Solid Waste Generation, Recycling, and Disposal in the United States Detailed Tables and Figures for 2008." U.S. Environmental Protection Agency, 5 January, 2009. Online. Available at: http://www.epa. gov/epawaste/nonhaz/municipal/pubs/msw2008data.pdf. (Accessed June 29, 2017).

NASAD (National Association of Schools of Art and Design). "Higher Education Arts Data Services (HEADS) Project, Chart 61: 'Art/Design Students by Degree Level and Ethnic Characteristics,"” HEADS Data Surveys, 31 January 2011. Online. Available to NASAD members with data access privileges at: https://secure3.vaultconsulting.com/HEADS/NASAD/ SpecReqForm.aspx (Accessed June 26, 2017).

Newsom, J.S (Director). “Miss Representation.” San Francisco, CA, USA: Girl's Club Entertainment, 2011. DVD. 
Papanek, V. The Green Imperative: Ecology and Ethics in Design and Architecture. New York, NY, USA: Thames \& Hudson, 1995.

Reardon, S. F., Baker, R. \& Klasik, D.. “Race, income, and enrollment patterns in highly selective colleges 1982-2004." Center for Education Policy Analysis, Stanford University, 3 August, 2012. Online. Available at: http://cepa.stanford.edu/content/race-income-and-enrollment-patterns-highly-selective-colleges-1982-2004. (Accessed June 25, 2017).

Speth, J. G. America the Possible: Manifesto for a New Economy. New Haven, CT, USA: Yale University Press, 2012.

The Steering Committee of the Environmental Paper Network. “The State of the Paper Industry Monitoring the Indicators of Environmental Performance.” Environmental Paper Network, 2 May, 2007. Online. Available at: http://www.greenpressinitiative.org/documents/StateOfPaperInd.pdf. (Accessed June 25, 2017).

\section{Biographies}

Eric Benson was born in Arizona and raised in mid-Michigan, where he later earned a BFA in graphic and industrial design from the University of Michigan in 1998. He worked professionally as a UI/UX designer at Razorfish and Texas Instruments before he received his MFA in design from the University of Texas at Austin in 2006. His MFA thesis became the internationally recognized and award-winning sustainable design website www.re-nourish.org. His work with Re-nourish was translated into an academic career that has since informed the evolution of his career as an Associate Professor of Graphic Design at the University of Illinois at Urbana-Champaign. His research and teaching at Illinois laid the foundation to create the Fresh Press Agri-Fiber Paper Lab. It explores the potential of papermaking to be a zero-waste activity, as well as environmentally sustainable, and a catalyst for a thriving local economy.

Benson has published and lectured internationally on the importance of sustainable design. His work has also garnered numerous design awards and has been seen in notable venues like The Walker Art Center, the Smithsonian Cooper Hewitt National Design Museum, the Hammer Museum, the Contemporary Arts Museum Houston, and RISD. He is also an active participant in the national design scene and local Champaign, Illinois community where he served on the National Steering Committee of the AIGA Design Educators Community (DEC) 
and on the board of directors at 4oNorth and Common Ground Food Co-op. Benson, in his spare time, is the host of Onward Radio, a podcast dedicated to discussing sustainable, service, and social design. (ebenson@illinois.edu)

John Jennings is Professor of Media and Cultural Studies and a Cooperating Faculty Member in the Department of Creative Writing at the University of California, Riverside. His work centers around intersectional narratives regarding identity politics and popular media. Jennings is co-editor of the Eisner Award-winning essay collection titled The Blacker the Ink: Constructions of Black Identity in Comics and Sequential Art, and co-founder/organizer of The Schomburg Center's Black Comic Book Festival in Harlem. He is co-founder and organizer of the MLK NorCal's Black Comix Arts Festival in San Francisco and also SOL-CON: The Brown and Black Comix Expo at the Ohio State University. Jennings sits on the editorial advisory boards for The Black Scholar and the new Ohio State University Press imprint New Suns: Race, Gender and Sexuality in the Speculative. He is currently the Nasir Jones Hiphop Fellow at the Hutchins Center at Harvard University. (ssum28@gmail.com)

Michael R. Gibson is the Coordinator of the Graduate Programs in Interaction Design and Design Research at the University of North Texas College of Visual Arts and Design (UNT CVAD). He is a Full Professor of Communication Design at UNT CVAD, and continues to build on his over 30 years of professional experience as a communication designer and project manager. He has also accrued over 20 years of professional and university-level experience facilitating and teaching communication and interaction design and design research, and has published and presented widely. Much of his work has involved forging and sustaining partnerships with academics and professionals from disciplines and fields outside design, particularly in the areas of children's health and education. (michael.gibson@unt.edu) 